\title{
On the Origin of Commons: Understanding Divergent State Preferences Over Property Rights in New Frontiers
}

\author{
Catherine Shea Sanger
}

A Dissertation Presented to the Graduate Faculty of the University of Virginia in Candidacy for the Degree of Doctor of Philosophy

Department of Politics

University of Virginia 


\section{"The first person who, having fenced off a plot of ground, took it into his head to say this is mine and found people simple enough to believe him, was the true founder of civil society."}

${ }^{1}$ Jean-Jacques Rousseau, "Discourse on the Origins and Foundations of Inequality among Men" in The First and Second Discourses, ed. Roger D. Masters, trans. Roger D. Masters and Judith Masters (New York: St. Martin's Press, 1964), p. 141 cited in Wendy Brown, Walled States, Waning Sovereignty (Cambridge, Mass.: Zone Books; Distributed by the MIT Press, 2010). 43. 


\section{Table of Contents}

Introduction: International Frontiers and Property Rights $\quad \mathbf{5}$

Alternative Explanations for Variance in States' Property Preferences $\quad 8$

Methodology and Research Design 22

The First Frontier: Three Phases of High Seas Preference Formation 35

The Age of Discovery: Iberian Appropriation and Dutch-English Resistance, Late-15th - Early 17th

Centuries 39

Making International Law: Anglo-Dutch Competition over the Status of European Seas, 17th Century 54

British Hegemony and Freedom of the Seas, 18th - 20th Centuries 63

$\begin{array}{ll}\text { Conclusion: What We've Learned from the Long High Seas History } & 70\end{array}$

Frontier in Flight: Early 20th Century Air Space $\quad 84$

Air Space as a New Problem of Law, 1880s - 1910

French, German, and British Preferences, 1910 - 1914

Comparing the Environmental and Geopolitical Explanations in Air Space 96

$\begin{array}{ll}\text { Air Space After } 1919 & 103\end{array}$

$\begin{array}{ll}\text { Conclusion } & 105\end{array}$

How High Can Sovereignty Fly? The US and USSR in Outer Space 115

From Frontier to Commons: 1957 - 1967

Superpower Preferences for Outer Space Property Rights 120

What Explains US and Soviet Preferences? 132

Conclusion: The Future Direction of Outer Space Regulation 141

The Frozen Frontier: Antarctica after WWII 150

The Theoretical Importance of Antarctica 153

The Antarctic Environment 155

A History of Ambiguous and Contested Property Rights 162

Asymmetric Exploitive Capacity and Divergent Preferences, 1940-1959 164

$\begin{array}{ll}\text { The Future } & 177\end{array}$

$\begin{array}{ll}\text { Conclusion } & 185\end{array}$

Summary of Findings $\quad 185$

Practical Implications and Theoretical Contributions 192 
4 of 195 


\section{Introduction: International Frontiers and Property Rights}

The laws and norms that regulate access and ownership of international spaces today are often seen as obvious or even inevitable. However, when new frontiers are first discovered their sovereignty status is often highly contested. International frontiers are domains that have become accessible and exploitable by states but do not yet exhibit entrenched property rights. Environments such as air space, outer space, the high seas, and the continental shelves were all once international frontiers. Frontiers can be newly discovered spaces - as the Americas or Antarctica were for their first discoverers - as well as domains that have long been known but only recently accessible - such the Moon before the 1960s.

Technological innovation often leads states to operate in a new frontier before its legal status is clear. As a result, there is often disagreement as to how a new frontier should be regulated. In particular, the creation of property rights — rules pertaining to sovereignty, access, and ownership — is foundational to any frontier's political development. The question motivating this dissertation is what leads states to favor the emergence of common versus national property rights in newly exploitable frontiers.

Property rights have important ramifications for the distribution of frontier resources, how that environment is used, and the likelihood of inter-state conflict therein. For example, because the high seas are common international property, ships of all kinds traverse the high seas without seeking prior permission: even nuclear 
submarines travel the oceans with impunity. By contrast, because air space has become national property, planes cannot enter into foreign air space without prior agreement and spy planes can be legitimately harassed when they fly over foreign territory. These different behavioral norms reflect frontiers' divergent property regimes.

Ultimately, some frontiers like the high seas become commons while others like air space become nationalized. These outcomes are not environmental inevitabilities. Rather, international commons and nationalized territories reflect man-made institutions. This is why in contemporary frontiers such as cyberspace, the deep sea, and the Arctic, access continues to be a key foreign policy consideration. Concerns over the status of international property have led President Obama to emphasize the need to "preserve access to the global commons" and "safeguard the sea, air, and space domains from those who would deny access." ${ }^{2}$ Openness in ocean, air, outer, and cyber space affords the US continued access to the resources and markets its prosperity is built upon. American attempts to reinforce status quo property norms are driven in part by fears about what sort of rules rising states will want to establish. China, in particular, is suspected of lusting after exclusive ownership over lunar and deep sea resources. ${ }^{3}$

Foreign policy analysts are right to worry about threats to international property regimes: these regimes are not inevitable outcomes and can have lasting impact. For example, current conflict over ownership of the Diaoyu/Senkaku Islands in the East China Sea reflects the different property norms associated with territorial and oceanic spaces. China, Taiwan, and Japan seek sovereignty over these islands not because the islands themselves are particularly valuable but because ownership of the islands confers 
exclusive sovereignty over adjacent maritime space where valuable hydrocarbons and fisheries are located. These states are competing over islands because land can be legally appropriated but maritime space cannot. If there was a strong international norm that uninhabited islands are common property, or if maritime territory could be nationalized directly, the nature of this dispute would be greatly changed. This is a good example of how different property norms, in this case governing ownership of land versus sea, that originated several centuries ago continue to flavor inter-state relations today.

Before these property rights become institutionalized, they are often strenuously debated. States often have very different preferences about how a new frontier should be governed. For example, when maritime technology made it possible for European ships to cross the Atlantic and Pacific oceans, Spain and Portugal argued that the first state to establish a maritime presence on the high seas could claim sovereignty while Dutch and later British statesmen argued that the oceans were common property. Similarly, we now take it for granted that air space above national territory belongs to subjacent states, but when aerial technology took-off at the turn of the twentieth century Germany and France wanted air space to become common property while Britain wanted it nationalized. And though it now seems natural that outer space is shared by all nations, in the 1950s when the Soviet Union and United States were making their first intrusions into this new domain they were also debating whether it would be open to all nations or somehow divided into distinct national zones.

This record of states advocating for divergent property regimes across different frontiers raises an important theoretical and practical question which is at the center of 
this dissertation: What causes states to develop divergent preferences regarding the sovereignty status of new frontiers? And, relatedly, Why would powerful states forgo exclusive, national ownership of new international frontiers and instead prefer open access and common property regimes?

To answer these questions the dissertation constructs two alternative explanations — one environmental and one geopolitical — of state preferences for frontier property rights (the dependent variable). It then assesses these hypotheses' ability to explain divergent state preferences for the high seas in the 15th to 17th centuries, air space in the 1900s and 1910s, outer space in the 1950s and 1960s, and Antarctica in the 1940s and 1950s. Across these cases I find much stronger support for the geopolitical than the environmental approach.

This chapter begins by introducing the environmental and geopolitical hypotheses tested throughout the dissertation. These hypotheses draw on existing literature related to norm creation, environmental regulation, and international conquest. The chapter concludes with a discussion of methodology and measurement.

\section{Alternative Explanations for Variance in States' Property Preferences}

In constructing generalizable explanations for variation in property preferences, I draw inspiration from three relevant literatures on environmental regulation, ${ }^{4}$ international norms and regimes, ${ }^{5}$ and territorial expansion. ${ }^{6}$ These literatures help us develop coherent alternative approaches for understanding variation in states' frontier 
preferences. Building hypotheses from these literatures also helps us to contextualize the contribution of this research project within existing international relations theory.

Drawing on these literatures I have constructed two distinct and generalizable approaches for explaining variation in frontier policy. Each lens is based on different assumptions about the main factors motivating frontier preferences. The environmental approach emphasizes properties of the frontier environment. The geopolitical approach emphasizes relational dynamics among states active in the frontier. The following table colloquially summarizes the different approaches.

\begin{tabular}{l|l|l|}
\hline Question: & Environmental Hypothesis: & Geopolitical Hypothesis: \\
$\begin{array}{ll}\text { Why would a powerful state } \\
\text { favor common over } \\
\text { national ownership of a } \\
\text { new international frontier? }\end{array}$ & $\begin{array}{l}\text { Because the frontier does } \\
\text { not contain valuable } \\
\text { resources. }\end{array}$ & $\begin{array}{l}\text { Because the state has } \\
\text { greater capacity to exploit } \\
\text { the frontier than others } \\
\text { states, and therefore wants }\end{array}$ \\
$\begin{array}{ll}\text { Because portions of the } \\
\text { access to the entire frontier } \\
\text { frontier cannot be } \\
\text { physically partitioned and } \\
\text { defended. }\end{array}$ & $\begin{array}{l}\text { without paying the cost of } \\
\text { excluding others. }\end{array}$ \\
\hline
\end{tabular}

\section{The Environmental Approach}

The environmental approach explains state preferences for frontier property rights in terms of the frontier's physical nature. The environmental explanation is based on two intuitive answers to the question of why powerful states might favor common over national ownership. First, states will not want to bother establishing national ownership in a frontier with low value. Second, states will not try to establish national ownership in a frontier that is physical resistant to enclosure. Following this logic, we would expect to 
find that the high seas, for example, became a commons because states did not believe ocean space was valuable or because they found it impossible to enclose. Similarly, the environmental approach would expect that air space became nationalized because states believed it was valuable and were able to physically enforce national ownership claims in that domain. As subsequent chapters will show, this is not consistent with the historical record. Nonetheless, the environmental approach needs to be tested across the case studies because it represents a strongly-held conventional wisdom for explaining state preferences in new frontiers. ${ }^{7}$

The environmental determinism underpinning this conventional wisdom reflects economic theories of environmental regulation as well as certain realist theories of territorial conquest. The environmental approach is most directly inspired by ecologist Garrett Hardin's insights regarding "the tragedy of the commons" and analyses that followed in his intellectual footsteps. ${ }^{8}$ In Hardin's view, a resources' physical nature determines the ways it gets used. Commonly held resources are often over-exploited, according to Hardin, because there are no incentives to restrain one's own usage if others also have unrestricted access. Hardin argued that the clearest way to avoid this tragedy of over-use is by enclosing commonly held resources. However, the nature of some resources makes enclosure unlikely. Specifically, their inherent excludability and divisibility - the ease of dividing and holding exclusive control over a portion of some resource - determines the feasibility of privatization or nationalization. In Hardin's framework, common property was therefore seen as the inevitable institutional outcome for non-excludable and indivisible resources. ${ }^{9}$ 
Similarly environmental-oriented explanations can be found in the literature on conquest and territorial expansion. In fact, some of the most respected explanations for patterns of conquest argue that it depends on the resource value to be extracted from occupying territory and the physical feasibility of effective occupation.

Several scholars of territorial conquest suggest that the best explanation for why great powers would forgo territorial expansion is that the territory in question contains little economic or strategic value or that it must be physically resistant to enclosure. ${ }^{10}$ According to John Mearsheimer, great powers almost always want more territory, resources, and space for themselves. ${ }^{11}$ States operating in a competitive, anarchic international system always at some level prefer exclusive to shared ownership of territory; they forgo it only when they lack the capability to take sole control. ${ }^{12}$ Robert Gilpin explains patterns of territorial expansion in similarly straightforward cost-benefit terms: states expand when technological innovations "increase or decrease the area over which it is profitable to extend military protection in exchange for revenue." ${ }^{13}$ And according to Fareed Zakaria's "state-centered realism," "central decision-makers will lead their nation to territorial expansion when they perceive an increase in state power and there are power vacuums available for conquest. Put simply, given the opportunity to expand, they will so long as foreign policy and military leaders have the capacity to marshal resources from across their state." ${ }^{14}$

States with the most to gain in absolute terms from a frontier will favor national ownership of that frontier, while states with less to gain from the frontier will favor common ownership. We should also expect states to nationalize valuable domains when 
they can physically divide and exclude access, and settle for common ownership when they physically cannot. Both of these hypotheses share the underlying assumption that states' preference for common or national ownership depends on the frontier's physical nature. When excludability and divisibility are low, frontiers cannot be physically divided and contained in discrete units, and states will accept common ownership by default. So long as the frontier contains attractive resources, when partition is physically possible, nationalization should be preferred. When excluding others from some portion of the frontier is very difficult or expensive, states will instead favor common ownership.

The key variables we need to explore, therefore, are the value, the excludability, and the divisibility of the frontier. As those variables increase in value, so should the incentive to nationalize. Excludability and divisibility captures the state's capacity to erect, monitor, and defend borders in the frontier. ${ }^{15} \mathrm{~A}$ frontier's value is measured in terms of military and economic utility.

To summarize these environmental hypotheses:

Environmental Hypothesis 1: States prefer to nationalize frontiers that contain high economic and military value and prefer to establish common ownership in frontiers with low value.

Environmental Hypothesis 2: States prefer to nationalize frontiers that are highly excludable and divisible and to establish common ownership in frontier with low excludability and divisibility.

\section{The Geopolitical Approach}

The environmental approach reflects the pervasive wisdom in early writing on environmental regulation and international rule-making. However, Elinor Ostrom's 
pathbreaking research on governance of international as well as domestic commons significantly challenged the environmental determinism that grew from Hardin's theory.

Ostrom and others convincingly argued that excludability and divisibility are in fact descriptions of man-made property rights and the capability of actors to manipulate natural resources. ${ }^{16}$

Ostrom was primarily interested in the origins of usage norms, rather than property norms. ${ }^{17}$ So though her theoretical contributions do not directly speak to this dissertation's central question — why states prefer national versus common property — her work is of great relevance in offering an alternative to the environmental perspective. Contrary to Hardin's environmental determinism, Ostrom showed that institutions governing resources reflect human actors' decisions and incentives, not just the nature of the resources themselves.

Building on Ostrom's analysis of how commons get used, Itai Sened's study of the origins of domestic property rights argues that, "the origin of private property and related individual rights is to be found in the political institutions that grant and enforce them and not in any set of moral principles or 'nature."' Sened shows how, at the domestic level, states institute private property rules strategically when doing so benefits societal groups that support the ruling government and when privatization increases the tax base from which the government draws. ${ }^{18}$

These critiques highlight the need for an alternative explanation for the sources of common and national ownership preferences.

Whereas the environmental approach focuses on the properties of the frontier, the 
geopolitical lens focuses on states' relative capacities to exploit frontier resources. To the question of why states might favor common instead of national ownership of a new frontier, the geopolitical answer is that the state must be better able to exploit frontier resources for economic and strategic purposes than other states that have access to the frontier. Because it has high exploitive capacity, it will want access to as much of the frontier as possible. Under a national ownership regime high capacity states would have to fight or bargain for a large share of the frontier, which could be quite costly. ${ }^{19}$ Under a common ownership regime, high capacity states get access to the entire frontier without having to pay costs of exclusion. This makes common ownership more attractive than national ownership.

This geopolitical explanation for state preferences in new frontiers draws primarily upon realist and rationalist theories of norm- and institution-construction. On the topic of international norms, realists contend that new norms may be articulated in terms of universal values and morality, but are actually deployed instrumentally to enhance powerful states' own wellbeing. ${ }^{20}$ Randall Schweller and Daryl Priess, for example, argue that powerful states create norms and institutions when they are at the peak of their relative power in order to lock-in favorable conditions that will protect their interests once their power has waned. ${ }^{21}$ States create norms strategically. To understand why states operating in a new frontier would favor national or common ownership, we need to identify the strategic implications of these different property regimes for different kinds of states. 
Within the literature on strategic norm construction, the best analogy to property rights is international economic institutions. Mercantilist trading arrangements are likely to be proposed by governments of less economically developed states while liberal trading arrangements tend to be championed by economic hegemons. Mercantilist institutions guarantee that a state has exclusive access to its own markets and denies those markets its rivals. However mercantilism's downside is that it requires states to forgo access to foreign-controlled markets. This is a worthy trade-off for states that lack the capacity to translate access to foreign markets into substantial economic and military gains. This is a bad deal, however, for states with the capacity to successfully compete in foreign markets. States with trading advantages want access to as many markets as possible, but it is expensive to gain access to foreign markets by physically excluding mercantilist competitors. A less costly way to secure access is by fostering liberal economic norms and open trading agreements. This is why economic hegemons typically favor liberal economic orders, and try to institutionalize free trade: they anticipate high gains because they can outcompete rival traders. ${ }^{22}$

Following this line of reasoning, to predict whether a great power will prefer common or national ownership in a new frontier, we need to consider the impact that the two ownership schemes will have on the state's economy and military. If a state has the capacity to nationalize the entire frontier without cost, that will probably always be its preference. But in new frontiers one state rarely has such a sizable, enduring advantage. More often, states must weigh the option of holding exclusive control over a specific portion of the frontier or sharing access across the entire frontier. Given this 
trade-off, we would expect states to favor common ownership when they have greater relative capacity to translate frontier resources into economic and military gains. And we would expect states to favor national ownership when they have inferior capacity to exploit frontier access for economic-military gains. States will favor nationalization or common ownership depending on their relative capacity to exploit frontier resources.

The geopolitical hypothesis is that states with relatively high capacity to exploit the frontier will favor common ownership. Common ownership will appeal to these states because it gives them access to the greatest share of frontier resources without having to pay the costs of exclusion. States with relatively less capacity, by contrast, to translate frontier resources into economic and military gains are likely to pursue national ownership. These low capacity states favor nationalization for at least one of two reasons: 1) to preserve some part of the frontier for themselves while they wait for their own exploitive capacity to grow and 2) to deny some portion of the frontier from rival exploiters to avert dire shifts in the balance of power among frontier powers.

To summarize, the geopolitical approach offers the following generalizable, testable hypothesis.

Geopolitical Hypothesis: States prefer to nationalize a frontier when they have relatively low capacity to exploit it for economic and military gains. States prefer to establish common ownership when they have relatively high capacity to exploit the frontier for economic and military gain.

It is worth noting that the environmental and geopolitical approach have opposite expectations regarding the implications of a frontier's economic and military value. In the environmental view, when a frontier has very valuable resources states should favor 
national ownership and when a frontier offers only minimally valuable resources states should prefer common ownership. In the geopolitical view, the more value that can be exploited from the frontier, the more states will favor common ownership. States with low capacity to exploit the frontier will prefer nationalization even when the frontier does not contain resources of great value to them if the frontier contains resources of high value to their other states.

In summary, the literatures on environmental regulation, norm construction, and territorial conquest reveal a number of variables that help explain why states prefer national or common ownership of new frontiers: the economic and military value of frontier resources, the feasibility of exclusion, and state capacity to extract valuable frontier resources. I have used these variables to construct two alternative approaches for explaining why states might favor common versus national ownership of new frontiers. The environmental approach hypothesizes that state preferences are determined by the value of frontier resources and the feasibility of physically partitioning the frontier. The geopolitical approach hypothesizes that preferences are determined by state's relative capacity to exploit the frontier for military and economic gain.

These hypotheses are not exhaustive, rather they are the most prominent coherent logics that can be derived from existing literature. The environmental and geopolitical approaches constitute a starting point for more comprehensive inquiry on frontier policy. 


\section{Wait, What About Domestic Politics?}

Both the environmental and geopolitical hypotheses focus on causal variables at the systemic level. There are also a number of factors at the domestic level that could plausibly explain variation in states' frontier preferences. Theories that explain states' international behavior (especially state expansion and norm-construction) with reference to domestic politics typically focus on one or more of the following factors: economic institutions, regime type, domestic political culture, and sectoral/industrial interests. ${ }^{23}$ There is good reason, both deductive and empirical, to bracket these factors from my analysis of states' preferences for frontier property rights.

Several scholars of norm creation argue that state-level norm entrepreneurs spread norms internationally that are valued domestically. ${ }^{24}$ Authors in this camp largely agree with their realist colleagues that successful international norms often reflect the preferences of the strongest states in the system. ${ }^{25}$ However, they argue that those preferences are derived as much from national identities as strategic, materialist costbenefit calculations. For example, John Ruggie connects changes in states' preferred international economic institutions with changes in "domestic authority relations."26 Ethan Nadelman argues that many regimes stem from great powers' "compulsion to convert others to one's beliefs and to remake the world in one's own image." ${ }^{27}$ As applied to frontier preferences, these arguments suggest we should consider how domestic ideational and institutional characteristics might influence preferences for national or common ownership internationally. While I agree that domestic politics certainly impact 
international politics in general, in this particular project I privilege systemic over domestic explanations for both deductive and empirical reasons.

First, on deductive grounds, I do not construct and test a domestic-level hypothesis because there is not a coherent domestic-level explanation that we would expect to generalize across different kinds of states and frontiers. There are often specific, idiosyncratic domestic factors that play a role in generating preferences for common or national ownership, and in the individual cases I try to bring those to light. But I have not identified a viable generalizable domestic-politics explanation that I would expect to work across cases. In general, it is difficult to explain specific foreign policy preferences with reference to qualities of political culture. In most nations, political culture exhibits complex and sometimes contradictory values, making it very difficult to develop generalizable propositions about the relationship between domestic ideology and international behavior. Given the absence of clear theoretical expectations about what kinds of domestic ideologies and institutions will favor common or national property rights in international frontiers, we will have to study this on a case-by-case basis.

Second, there are empirical reasons to bracket domestic variables. None of the important variables found in existing theories of domestic preference formation correlate with frontier preferences in the cases examined in this study.

The most promising domestic characteristic that might matter for frontier preferences is whether a state is characterized by more mercantilist or liberal economic institutions. Empirically, however, we have good reason to think this is a poor predictor 
of frontier policy. The Soviet Union employed aggressively mercantilist policies after WWII at the time time it advocated common ownership of Antarctica. At the same time that Germany was pursuing mercantilist relations within "Middle Europe" and colonies abroad, it was advocating for common ownership in air space. ${ }^{28}$ Meanwhile, liberal Britain advocated for the nationalization of air space prior to WWI and Antarctica after WWII. Because states' adoption of mercantilist versus liberal trading policies does not strongly correlate with frontier property preferences, we have good reason to doubt a causal relationship between domestic economic system and frontier preferences.

Domestic political regime-type also does not correlate with frontier preferences. We might expect democracies to favor open ownership norms since they promote openness in domestic political affairs. On the other hand, we might expect those same polities to pursue nationalization abroad as a reflection of the value placed on private property in many democratic states. Empirically, there is no connection between domestic regime type and frontier preferences. The Soviet Union was a repressive, communist state throughout the 1950s and 1960s, yet in that period it advocated openness in Antarctica but defended sovereignty in both air and outer space. In the early 20th century both France and Britain had (for the time) solidly democratic political institutions but France favored openness and Britain closure of air space.

Scholars of territorial conquest have argued that states' enthusiasm for territorial expansion is often influenced by domestic political culture. For example, Michael Doyle and Sharon Korman have both argued that states with xenophobic, militant political cultures will be more enthusiastic about conquest than states with more pluralistic, 
pacifistic national identities because they want to bring their superior institutions and race to foreign lands. Similarly, some lands have been more susceptible to conquest because their inhabitants were seen to be less worthy of political independence. For example, in the 16th-19th centuries, European statesmen often viewed "barbarian" and non-Christian peoples as not only susceptible to conquest but morally in need of acquisition. ${ }^{29}$ However, this line of argument does not apply very well to my study because it incorporates uninhabited and extra-terrestrial frontiers.

Liberal theories that focus on the power of domestic interest groups, and bureaucracies over foreign policy outcomes offer less plausible explanations for frontier policy. ${ }^{30}$ Policies for new frontiers are, by definition, new and in general the implications of national versus common ownership for domestic interest groups and bureaucracies is unclear. In the early years of a frontier's exploitation, therefore, it is unlikely that one property norm or another has a strong and independent domestic constituency. Domestic interest groups take time to form and exert power over their governments. Alreadypowerful and entrenched lobbies are unlikely to have strong interests when it comes to new frontiers because those frontiers involve new issues and new technologies. For example, air space was nationalized well before the rise of private air industries and outer space became common property decades before private actors were significantly involved in outer space exploration. Meanwhile, within-government bureaucracies organized around new frontiers like NASA or the Air Force are typically created at the same time that foreign policy leaders are deciding what property norm to support. These bureaucracies have not had time to cultivate significant influence over policy outcomes 
during the frontier period. ${ }^{31}$ For these reasons, the domestic audience should, in general, be relatively pliant to the arguments of foreign policy leaders on the topic of international property rights. Foreign policy makers are, for the same reason, likely to be more responsive to the actions and interests of other states than domestic interest groups. As a result, foreign policy leaders will have greater decision-making autonomy than in more established political issues and generally prioritize national interests over demands of narrowly-focused interest groups or bureaucracies.

In sum, I have not developed a generalizable hypothesis concerning the influence of domestic ideology, institutions, or interest groups on both deductive and empirical grounds. Deductively, there is not a logically coherent or generalizable domestic level explanation for why some states would favor national ownership and others common ownership of new frontiers. Empirically, the domestic-level variables most prominent in existing literature do not correlate with frontier preferences and so are unlikely to be causally salient across cases. Instead of testing a particular domestic hypothesis across all cases, I am attentive within individual cases to the ad hoc influence of domestic politics on frontier preferences. In particular, I look for ways in which domestic politics interact with environmental and geopolitical variables to explain variation in preferences for national and common ownership across states.

\section{Methodology and Research Design} Measuring the Dependent Variable 
The dependent variable is the preferences of critical states for common or national ownership of the frontier.

In order to understand the origins of property regimes, we need to understand the frontier preferences of states that are first active in the frontier and possess a combination of military, economic, and political power to exert preferences over property rights in the frontier. For a new norm or regime to take root almost always requires the support of "critical states," which Finnemore and Sikkink define as states "without which the achievement of the substantive goal is compromised." 32 These critical states must have the capacity to coerce, induce, or persuade others to accept a new norm. Critical states are also often enmeshed in international organizations from which they can codify and spread new norms. For these reasons critical states tend to be great powers in the international system. In frontier regimes specifically, critical states are likely to be great powers are because, given their substantial economic and technological resources, they are almost always among the states to first operate in a new frontier. And because these are states with the capacity to influence regime outcomes, they are also the states most likely to seriously consider and reveal their property preferences. To understand where property regimes come from, therefore, in each frontier we need to focus primarily on the preferences of critical states with sufficient interest as well as military, economic, and political capacity to effectively assert or resist national ownership. In the high seas I therefore focus on Spain, Portugal, the Netherlands, and England/ Britain. In air space France, Germany, and Britain were the main players and in outer space the United States and Soviet Union forged property norms. In Antarctica, British, Argentine, Australian, 
American, and Soviet preferences are key. The preferences of these critical states is the dependent variable to be measured in this study.

To measure states' preferences we can look at foreign policy leaders' behavior in the frontier and at home to see whether they are taking steps to nationalize or to establish common ownership. Specifically, we can infer preferences from public statements of executive policy; pertinent national legislation, testimony and debate; private documents reflecting decision-makers' preferences; drafts submitted for international legislation; and transcripts from foreign policy conferences and negotiations. Technology policy is particularly revealing because it tells us whether governments invested in technologies that would make nationalization more or less feasible.

\section{Qualitative Case Studies}

This dissertation analyzes the bases of states' preferences for common versus national ownership across four different frontiers: air space, outer space, high seas, and Antarctica. These frontiers were selected for their importance in current day-to-day international relations but most importantly because they offer variation on the dependent variable. In each of these frontiers some critical states initially favored national ownership while others favored common ownership. These frontiers exhibit interesting variation in other ways as well. Air and outer space have become associated with different property rights regimes despite both being vertical spaces with similar physical properties. Antarctica and the high seas they exhibit divergent property rights 
despite both being part of the Earth's surface. Property rights debates in Antarctica involved many states, in air space and the high seas three primary states, and in outer space only two.

For this project, a "case" or data-point is a state's preferences during the frontier period. In the high seas, the frontier period lasted for several centuries and I therefore have six cases from that frontier: three from the 15th and 16th centuries (Spain/ Portugal, United Provinces, England), two from the 17th century (United Provinces, England), and one from the 18th - 20th century (Britain). In air space there are three cases: France, Germany, and Britain in the early 20th century. In outer space the United States and the Soviet Union in the 1950s and 1960s adds two more cases. In Antarctica, I focus on five additional cases from the 1940s and 1950s: Argentina, Australia, Britain, United States, and Soviet Union. In total, therefore, this dissertation includes 16 cases of state preference formation for frontier property rights across four frontiers.

I use a mix of qualitative research tools within each case study to determine whether hypothesized causal factors actually induced observed variation in states' preferences. Congruence testing compares the empirical expectations of our hypotheses against the actual preferences exhibited by states, helping to exclude some hypotheses and focusing our attention on most-likely explanations. ${ }^{33}$ When possible within-case process tracing assesses whether observed correlations are actually causal.

For each case the first step is to determine when the frontier period begins and ends. This is the time frame in which property regime preferences - our deponent variable — are initially developed because states must, for the first time, seriously 
consider what kind of property regime they prefer. A frontier period begins with sustained exploration and exploitation of a previously impenetrable domain. The frontier period ends once a property regime is established. Following these definitions air space's frontier period was the 1890s through the early 1920s; outer space's the late 1950s through the 1960s; the high seas' the 15th, 16th, and 17th centuries; Antarctica's the 1940s through the 1950s.

Frontiers can be newly discovered spaces - as the Americas or Antarctica were for their first discoverers - as well as domains that have long been known but only recently accessible - such the Moon before the 1960s. Frontiers can also emerge from territorial power vacuums when they make territory without clear sovereignty norms newly accessible to outside powers. ${ }^{34}$ The frontier period ends when codified rules or uncodified behavioral norms regarding access are established, "cascading" among states active in the frontier and often becoming institutionalized in the form of multi-lateral treaties. ${ }^{35}$ These norms, laws, and the behaviors that reinforce them compose international property regimes. ${ }^{36}$

We infer that a property regime has been instantiated when status-quo reproducing behavior is treated as normal, natural, and largely uninteresting while behavior that deviates from the status quo is treated as strange, unusual, and noteworthy. Importantly, therefore, I look for evidence that a norm has been challenged and endured before determining that a property regime has been established. In all cases, there are moments when property rights are violated. What matters is whether violations are exceptions that prove the rule or if they reveal the absence of recognized 
rules. When President Eisenhower sent spy planes into Soviet air space in the 1950s and 1960s, for example, he did so secretly because he knew this action violated international law. The way states violate property norms often reveals the very existence of those norms.

There are subtle variations in the nature of ownership and access across different domains but most property regimes fall somewhere on a national-to-common ownership spectrum. Frontiers that become national property have been divided into distinct spaces over which states assert sovereign authority and jurisdiction. ${ }^{37}$ Examples of frontiers that have became national property include: national air space after the 1920s, large swaths of Africa by Europe between the 1880s and 1910s, and continental shelves after the 1950s. Frontiers that become common property will generally be understood as spaces "over which no single nation has a generally recognized exclusive jurisdiction" 38 or "realms that have remained outside the jurisdiction of any country." 39 Common property is therefore distinct from non-property or not-yet-regulated frontiers because in common property there is international agreement over the lack of exclusive ownership. ${ }^{40}$ Frontiers that become common property include: the high seas since the 18th century, international air space since the 1920s, and outer space since the 1960s.

\section{Organization of the Dissertation}

Armed with clear concepts and testable hypotheses, we can now delve into the case studies. Each subsequent chapter addresses a specific frontier and the property preferences of the critical states active in that frontier's initial political development. For 
each chapter we will evaluate how well the environmental and geopolitical approaches explain why some states initially favored common ownership while others preferred nationalization. Although the first frontier to be discussed, the high seas, presents an explanatory challenge to both the environmental and the geopolitical hypotheses, by the end of the dissertation readers will see the superior explanatory power of the geopolitical over the environmental approach. Some practical and theoretical implications of this finding will be discussed in the conclusion. 


\section{Notes:}

2 Barack Obama, National Security Strategy (Washington, DC: The White House, 2010) p. 14, 49-50.

${ }^{3}$ Scott Jasper ed., Securing Freedom in the Global Commons (Stanford, CA: Stanford Security Studies, 2010); Abraham M. Denmark and James Mulvenon, Contested Commons: The Future of American Power in a Multipolar World (Washington, DC: Center for a New American Century, 2010); Barry Posen, "Command of the Commons: The Military Foundation of U.S. Hegemony" International Security 28, 1 (Summer 2003); Robert Keohane and Ellinor Ostrom eds, Local Commons and Global Interdependence: Homogeneity and Cooperation in Two Domains (Thousand Oaks, CA: SAGE, 1995); William Broad, "China Explores a Frontier 2 Miles Deep" New York Times (September 11, 2010); Irene Klotz, "Does China Want To Own The Moon?" Discovery News Online, Oct. 20, 2011; Accessed online on Oct. 26, 2011.

${ }^{4}$ Mancur Olson The Logic of Collective Action (Cambridge MA: Harvard University Press, 1965); Garrett Hardin, "The Tragedy of the Commons" Science 162, 2859 (December 13, 1968); Elinor Ostrom, "How Types of Goods and Property Rights Jointly Affect Collective Action" Journal of Theoretical Politics 15, 239 (2003); Oran Young, International Cooperation: Building Regimes for Natural Resources and the Environment (New York: Cornell University Press, 1989).

${ }^{5}$ Stephen Krasner, Sovereignty: Organized Hypocrisy (Princeton, NJ: Princeton University Press, 1999); Alastair Iain Johnston, Social States: China in International Institutions, 1980-2000 (Princeton, NJ: Princeton University Press, 2007); Jeffrey Checkel, "Norms, Institutions, and National Identity in Contemporary Europe" International Studies Quarterly (1999); Jeffrey Checkel, The Constructivist Turn in International Realtions Theory, World Politics 1998; Thomas Risse, Stephen Ropp, and Katherine Sikkink eds, The Power of Human Rights: International Norms and Domestic Change (Cambridge, UK: University of Cambridge, 1999); Martha Finnemore and Katherine Sikkink, "International Norm Dynamics and Political Change" International Organization 52, 4 (Autumn 1998); Anne-Marie Slaughter Burley, "International Law and International Relations Theory: A Dual Agenda" American Journal of International Law 87, 205 (1993).

${ }^{6}$ I lean particularly on Tanisha M. Fazal, State Death: The Politics and Geography of Conquest, Occupation, and Annexation (Princeton 2007). See also Peter Lieberman, Does Conquest Pay? The Exploitation of Occupied Industrial Societies (Princeton University Press, 1996); Richard Rosecrance, The Rise of the Trading State: Commerce and Conquest in the Modern World (Basic Books, 1986).

${ }^{7}$ On environmental determinism as conventional wisdom see P.K. Mitchell, "Distributing the Fish: TwoLevel Games in the Commons" International Studies Review (2010); Susan Hanna, Carl Folke, and KarlGoran Maler, Rights to Nature: Ecological, Economic, Cultural, and Political Principles of Institutions for the Environment (Washington, DC: Island Press, 1996); O. Schachter, Sharing the World's Resources (Columbia University Press, 1977); Michael Goldman ed., Privatizing Nature: Political Struggles for the Global Commons (Rutgers University Press, 1998); John A. Baden and Douglas S. Noonan, eds. Managing the Commons (Indiana University Press, 1998); Per Magus Wijkman, "Managing the Global Commons" International Organization (Summer 1982); Elinor Ostrom, Governing the Commons: The Evolution of Institutions for Collective Action (Cambridge University Press, 1990).

8 Paul Samuelson, "The Pure Theory of Public Expenditure" Review of Economics and Statistics 36 (November 1954); William H. Riker and Peter C. Ordeshook, An Introduction to Positive Political Theory (Cambridge: MIT Press, 1973); Mancur Olson, The Logic of Collective Action: Public Goods and the Theory of Groups (New York: Schocken Books, 1971). For more contemporary extensions see John M. Stopford, Susan Strange, and John S. Henley, Rival States, Rival Firms: Competition For World Market Shares (Cambridge University Press, 1991); R.E. Hassner, "To Halve and to Hold": Conflicts over Sacred Space and the Problem of Indivisibility" Security Studies, 2003. For an intellectual history and critique see Bonnie McCay, "Common and Private Concerns" in Rights to Nature: Ecological, Economic, Cultural, and Political Principles of Institutions for the Environment (Washington DC: Island Press, 1996); Daniel W. Bromley, "The Commons, Property, and Common-Property Regimes" in Bromley ed. Making the Commons Work: Theory, Practice, and Policy (San Francisco, CA: Institute for Contemporary Studies, 1992).

${ }^{9}$ Hardin, "Tragedy"; Richard A. Posner, Economic Analysis of the Law, 5th ed. (Aspen Publishers, 1998), 45-56. 
${ }^{10}$ Fareed Zakaria, From Wealth to Power:The Unusual Origins of America's World Role (Princeton University Press, 1999), 18-19.

${ }^{11}$ John Mearsheimer, The Tragedy of Great Power Politics (W.W. Norton, 2001), Ch. 1; Eric J. Labs, "Beyond victory: Offensive Realism and the Expansion of War Aims" Security Studies, 6:4 (1997). See especially Labs' discussion of opportunity as a driver of expanded war aim, p. 19-21. See also Zakaria's description of how classical realism addresses variation in territorial expansion, Zakaria, Wealth to Power, ch. 1.

${ }^{12}$ As Thomas Holdich wrote in 1916, "The territorial limit, or frontier, of any community, State or nationality which has established a constitutional government is usually a fair indication of the distance from the central seat of control that the arm of the law can reach." Thomas H. Holdich, Political Frontiers and Boundary Making (MacMillian and Co, 1916).

${ }^{13}$ The determinants of this cost-benefit analysis may be historically contingent, but generally stem from leaders' understanding of the economic costs of exclusive ownership or occupation and the economic and political benefits of openness. Gilpin, War and Change, 60-61. As applied to property rights, this costbenefit calculation plays out, according to Thrainn Eggertsson, as follows: "In each case, the answer depends on the characteristics of costs in production, exclusion, and governance. Prohibitive exclusion costs render any form of exclusive ownership impractical and make open access the optimal solution; relatively low internal governance costs and high exclusion costs can make communal property the ideal arrangement; and factors that sharply reduce exclusion costs make individual private property more attractive." Thrainn Eggertsson, "The Economics of Control and the Cost of Property Rights" in Hanna et. al. Eds. Rights to Nature, p.166.

${ }^{14}$ Zakaria, Wealth to Power, ch. 2. See also Mearsheimer, Tragedy of Great Power Politics, Ch. 1 and p. 86; Michael Doyle, Empires (Ithaca: Cornell University Press, 1986), 129. Although writing from a very different theoretical perspective, Richard Rosecrance's The Rise of the Trading State similarly argues that states engage in conquest when territory contains valuable resources that cannot be acquired through more peaceful, commercial strategies. Rosecrance expects states to forgo conquest when a territory does not contain valuable resources or when they can get those resources through trade. As physically occupying territory has become more difficult, conquest has become less common. Maintaining capable militaries became steadily more expensive after the mid-19th century, while nationalism generates domestic resistance to occupation. Rosecrance is essentially arguing that leaders' decision to engage in territorial conquest derives from the feasibility of physical occupation and the economic value of the territory in question. Richard Rosecrance, The Rise of the Trading State: Commerce and Conquest in the Modern World (Basic Books, 1986) 156 and also 160-161.

${ }^{15} \mathrm{~A}$ frontier is excludable and divisible when states can physically erect, monitor, and defend boundaries in some portion of the frontier. Value can be measured in terms of absolute military and economic utility. Although the "rivalry" of goods features prominently in Hardin-esqu literature on environmental regulation, I do not focus on rivalry here because I am interested in entire frontiers which can almost always be shared.

${ }^{16}$ Elinor Ostrom, Governing the Commons: The Evolution of Institutions for Collective Action (Cambridge University Press, 1990). See also Richard Barnes, Property Rights and Natural Resources (Portland, OR: Hart Publishing, 2009) and Robert Bates, "Contra Contractarianism: Some Reflections on the New Institutionalism" Politics and Society 16, $2-3$ (June 1988).

17 The tragedy of the commons is highly conditional, Ostrom argued, and under some circumstances appropriators of commonly held resources overcome the tragedy by developing usage norms that minimize over-exploitation. According to Ostrom the ability of actors to avoid over-exploitation of common resources depends largely on the availability of "generalized norms of reciprocity and trust" and the availability of monitoring mechanisms. Ostrom, Governing the Commons. Ostrom and Robert Keohane went on to document the tremendous variation in levels of cooperation that actors exhibit in their use of commons. Robert Keohane and Elinor Ostrom eds, Local Commons and Global Interdependence: Homogeneity and Cooperation in Two Domains (SAGE 1995); See also David Feeny, Fikret Berkes, Bonnie J. McCay, and James M. Acheson, "The Tragedy of the Commons: Twenty-Two Years Later" Human Ecology 18, 1 (March, 1990). 
${ }^{18}$ Itai Sened, The Political Institution of Private Property (Cambridge University Press, 1997), 1, 29-31. See also Michael Goldman ed., Privatizing Nature: Political Struggles for the Global Commons (Rutgers University Press, 1998).

19 James D. Fearon,"Rationalist Explanation for War" International Organization 49 (1995); James D. Fearon, "Bargaining, Enforcement, and International Cooperation" International Organization 52, 2 (Spring 1998).

${ }^{20}$ Stephen D. Krasner ed., International Regimes (Cornell University Press, 1983); Ward Thomas, "Norms and Security: The Case of International Assassination" International Security 25, 1 (Summer 2000); Ward Thomas, The Ethics of Destruction: Norms and Force in International Relations (Ithaca, New York: Cornell Studies in Security Affairs, Cornell University Press, 2001); Judith Kelley, "Assessing the Complex Evolution of Norms: The Rise of International Election Monitoring" International Organization 62, 02 (2008); Andrew Kydd. "Trust Building, Trust Breaking: The Dilemma of NATO Enlargement" International Organization 55, 4 (2001). Kyddd argues that NATO's most powerful members encourage new members to adopt more democratic practices not because they value democracy per se but because it tests new members' trust-worthiness.

${ }^{21}$ Randall Schweller, and Darryl Priess, "A Tale of Two Realisms: Expanding the Institutions Debate" Mershon International Studies Review 41 (1997).

${ }^{22}$ David A. Lake, Power, Protection, and Free Trade: International Sources of U.S. Commercial Strategy, 1887-1939 (Cornell University Press, 1988); David A. Lake, "Leadership, Hegemony, and the International Economy: Naked Emperor or Tattered Monarch with Potential?” International Studies Quarterly 37, 4 (December, 1993); G.J. Ikenberry, "The future of International Leadership" Political Science Quarterly (1996); G. John Ikenberry, Liberal Leviathan: The Origins, Crisis, and Transformation of the American World Order (Princeton University Press, 2012); Charles P. Kindleberger, The World in Depression, 1929-1939 (University of California Press, 1973); Stephen D. Krasner, "State Power and the Structure of International Trade" World Politics 28, 3 (April 1976), 343; Robert Keohane, After hegemony: Cooperation and Discord in the World Political Economy (Princeton University Press, 1984).

${ }^{23}$ Andew Moravcsik, "Taking Preferences Seriously: A Liberal Theory of International Politics," International Organization 51, 4 (Autumn, 1997). See also Michael W. Doyle, "Liberalism and World Politics" The American Political Science Review Vol. 80, No. 4 (December, 1986).

${ }^{24}$ Henry R. Nau, At Home Abroad: Identity and Power in American Foreign Policy (Cornell University Press, 2002); Thomas Risse-Kappen, "Opinion, Domestic Structure, and Foreign Policy in Liberal Democracies', World Politics, 43 (4) 1991; Thomas Risse-Kappen, Cooperation Among Democracies: The European Influence on U. S. Foreign Policy (Princeton, New Jersey: Princeton University Press, 1995); Colin Dueck, Reluctant Crusaders: Power, Culture, and Change in American Grand Strategy (Princeton, N.J.: Princeton University Press, 2007); John M. Owen IV, "The Foreign Imposition of Domestic Institutions," International Organization (2003); Frank Schimmelfennig, The EU, NATO, and the Integration of Europe (Cambridge University Press, 2003); Ann Florini, The Evolution of International Norms, International Studies Quarterly 1996.

${ }^{25}$ Ethan A. Nadelmann, "Global Prohibition Regimes: The Evolution of Norms in International Society" International Organization 44, 4 (Autumn, 1990), 485.

${ }^{26}$ John Gerard Ruggie, "International Regimes, Transactions, and Change: Embedded Liberalism in the Postwar Economic Order" International Order 36, 2 (Spring, 1982).

${ }^{27}$ Governments are more or less likely to base foreign policies on these ideational impulses depending on "the political influence of domestic and transnational moral entrepreneurs as well as that of powerful individual advocates within the government." Nadelman, "Global Prohibition," 481.

${ }_{28}$ Paul M. Kennedy, The Rise of the Anglo-German Antagonism, 1860-1914 (Boston: Allen and Unwin, 1980), 226, 231-2; Peter Gourevitch, Politics in Hard Times: Comparative Responses to International Economic Crises (Cornell University Press, 1986), pp. 84-99.

${ }^{29}$ Doyle, 324. Sharon Korman, The Right of Conquest: The Acquisition of Territory by Force in International Law and Practice (Oxford, England: Clarendon Press, 1996), 42. 
${ }^{30}$ Graham T. Allison, Essence of Decision (Boston: Little, Brown, 1972); James R. Kurth, "The Political Consequences of the Product Cycle: Industrial History and Political Outcomes" International Organization Vol. 33, No. 1 (Winter, 1979); Jeff Frieden, "Sectoral Conflict and Foreign Economic Policy, 1914-1940" International Organization Vol. 42, No. 1, The State and American Foreign Economic Policy (Winter, 1988). ${ }^{31}$ An exception is the high seas, where several centuries passed between the frontier's initial penetration and regime formation. For that reason domestic interest groups did form during the frontier period and exert considerable influence on frontier policy.

32 Martha Finnemore and Katherine Sikkink, "Norm Dynamics and Political Change" International Organization (Autumn 1998), 901. Early scholarship on regulatory norms focused on the role of domestic and transnational activist groups, international organizations, and weak states as the primary instigators of norm creation and diffusion. It was thought that norms were tools used by weaker actors to compensate for their lack of economic and military power. However, more recent research suggests that great powers are in fact often responsible for norm creation. Finnemore and Sikkink, "Norm Dynamics;" Krasner, International Regimes; Ruggie; Katenstein 1996.

${ }^{33}$ On congruence testing: Alexander L. George and Andrew Bennett, Case Studies and Theory Development in the Social Sciences (MIT Press, 2005); James Mahoney and Dietrich Rueschemeyer, Comparative Historical Analysis in the Social Sciences (Cambridge University Press, 2003).

${ }^{34}$ Frontiers can even, in principle, be technological "spaces" rather than naturally-occurring physical spaces. However, explanations of physical frontier policies may not perform as well when applied to technological spaces. For European and later "great power" states the following domains were frontiers: Continental Margin in the mid-20th century; Territorial Seas in the Roman Empire and early Middle Ages; High Seas in the 15th - 17th centuries; North and South America in the 15th - 18th centuries; South and East Asia in the late 15th - 18th centuries; North and West Africa in the late 19th century; Air Space in the 1880s - 1920s; Antarctica in the early - mid 20th century; Deep Seas in the 1900s - 1950s; Outer-Space in the 1950s - 1960s; The Moon in the 1960s; Electromagnetic Frequencies in the mid-20th century; The Arctic Circle in the second half of the 20th century; Cyberspace in the late 20th - early 21st centuries. ${ }^{35}$ Finnemore and Sikkink usefully describe the life cycle of international norms, distinguishing between an initial stage of "norm emergence" - when norm entrepreneurs float new normative frameworks - and a second "norm cascade" stage when these entrepreneurs' favored norms are adopted by others. The concept of norm cascades stems from Sunstein 1997. Finnemore and Sikkink, "International Norm Dynamics."

${ }^{36}$ A regime is "a relatively stable collection of practices and rules defining appropriate behavior for specific groups of actors in specific situations." James G. March and Johan P. Olsen, "The Institutional Dynamics of International Politics Orders" International Organization 52, 4 (Austumn 1998), 948. A property regime is therefore a collection of formal or informal norms, rules, and patterns of behavior pertaining to ownership and access in a given issue-area, environment, or arena.

${ }^{37}$ Frontiers that have become national property exhibit at least some of the following characteristics: They have been divided into distinct spaces over which states assert authority and jurisdiction; States make public assertions to sovereign authority over some portion of the domain; Borders are physically erected, defended, and/or monitored. If this is not possible, borders are politically erected through mutual understanding; Legal agreements exist that codify ownership claims; States retaliate and threaten to retaliate if borders are transgressed, indicating their belief that they hold legitimate sovereignty; States seek permission before entering a part of frontier claimed by another, indicating that the non-owner recognizes the owner's legitimate sovereignty claims and/or the owner's willingness to defend those claims; Attempts to enter another state's claimed area without prior permission are conducted secretly, indicating recognition of ownership claims and the deviance of their behavior.

38 Per Magnus Wijkman, "Managing the Global Commons" International Organization 36, 3 Summer 1982: 511.

${ }^{39}$ Seyom Brown et al., Regimes for the Ocean, Outer Space, and Weather (Washignton DC: Brookings, 1997), Ch 1. 
${ }^{40}$ Frontiers that have become common property exhibit at least some of the following characteristics: They are accessible to all states with the capacity and desire to operate therein; States make public assertions that the frontier is open to all; There are no physical or political borders regulating access; Legal agreements exist that codify common ownership; States can move freely without recrimination across the domain; States do not seek the permission of others before accessing the domain; States do not attempt to transit the domain in secret. 
34 of 195 